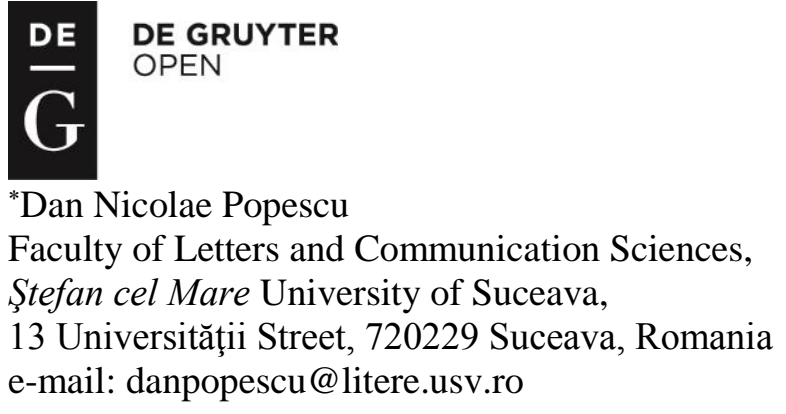

\title{
BETWEEN THE NORMATIVE AND THE PERFORMATIVE: SEX, PARODY, AND OTHER (IN)TRACTABLE ISSUES IN GEOFFREY CHAUCER'S MILLER'S TALE
}

Abstract

\begin{abstract}
The article explores how Geoffrey Chaucer's Canterbury Tales discusses human sexuality as a major thematic concern in both its normative and its performative dimension, and sex, an (in)tractable issue throughout the Middle Ages, as a core motif that helps the author to explore the extant tension between the human and the ideal. On the other hand, parody and audience/reader response are important instruments in the medieval poet's strategy of approaching delicate matters in his pilgrims' tales, which become readily apparent in the 'order of play' in which the tales come. The Miller disrupts the story-telling order because this disruption serves Chaucer's purpose of questioning the validity of the courtly love concept through a parody of courtly romance, much like the poet's purported distancing from the heretical views upon human sexuality expressed by the Miller can be decoded as an attempt to restore the balance of power between doctrinal inflexibility and humans' timeless desire for the natural.
\end{abstract}

Keywords: church doctrine, human sexuality, parody, courtly love, fabliau

The societal climate of the Middle Ages was undoubtedly regulated by the strict behavioural code of the church. Patristic literature stipulated that Christ and Virgin Mary were absolute models that men and women should strive to emulate in order to obtain salvation (Augustine, 1999). From crib to coffin, medieval life was guarded, guided and chastised in line with the uncompromising principles of the Christian doctrine. Inevitably, tensions arose between the ideal and the human as it was particularly difficult to live by divine standards in not so divine a world. Geoffrey Chaucer's The Canterbury Tales chronicles this tension brilliantly, bringing onto the stage an array of pilgrims and characters who do not always behave according to the religious ideal, especially when it comes to their sexual behaviour. At face value, Chaucer acts as a conventional love poet who tries to accommodate his interest in gender differences and sexuality with the strict normative mandates of Christian doctrine, while, at a deeper level, the same Chaucer joins an enduring philosophical debate over the nature of love trying to capitalize on discursive arguments afforded by a "number of ancient and medieval currents of thought in which, by the late Middle Ages, questions of sexuality and questions of agency and autonomy had come to intersect" (Miller, 2004: 3). Consequently, The Canterbury Tales proposes human sexuality as a major thematic concern in both its normative and its performative dimension, while sex as a core motif helps the author to explore the extant tension between the human and the ideal by attempting to bring under the same roof the patristic doctrine, the philosophical debate, and the demands of practical reason.

In Chaucer's day, sexual behaviour was believed, quite literally, to be able to dispatch a person to heaven or to hell. Chaucer's protagonists go to great lengths to reflect the poet's moral and intellectual

\footnotetext{
* Dan Nicolae Popescu is a Lecturer at the Ștefan cel Mare University of Suceava, Romania, and holds a Ph.D. in Anglo-American literature. His academic interests include literary, cultural, and translation studies, with a particular emphasis on Medieval English literature and the literature of the American South.
} 
dilemma: is it really possible to reconcile the normative dimension of sexual behaviour controlled by church doctrine (the ideal approach) with its performative dimension, namely the down-to-earth, imperfect and sinful manner in which people interact sexually (the human approach)? The medieval world Chaucer knew and wrote about was ruled by the iron rod of doctrine that provided a single framework of reference for all things human: God's creation. As such, caution was to be exercised in order to write about aspects of sexuality that fell short of the professed ideal, such as adultery, fornication, or lust, as the writer, when putting the sexual mores of his age into context, inevitably comes to manipulate a certain comedy of discrepancy that appears when the ideal representation of sexuality clashes with its actual counterpart. Chaucer has his pilgrim narrators move about unrestrained in a sociocultural environment that interweaves elements of the ideal behavioural norm (hagiographies, biblical allusions, invocations of saints and biblical characters) with instances of the actual (adultery, fornication, sexual abuse and, last but not least, clerical corruption).

The best way Chaucer manages to handle this comedy of discrepancy between the ideal and the actual is through the use of parody, which triggers a certain response on the part of the audience/readers. Parody and audience/reader response are important instruments in Chaucer's strategy of approaching delicate matters in the tales told by the pilgrims, and they become readily apparent in the 'order of play' in which the tales come, as the Knight's courtly romance is succeeded by the Miller's bawdy fabliau. That the Miller's Tale is a parody of the Knight's Tale is as plain as the wart on the Miller's nose. According to Linda Hutcheon, parody may be defined as "imitation characterized by ironic inversion, not always at the expense of the parodied text", or as "repetition with critical distance, which marks difference rather than similarity" (1985: 6). In its use of judgment and comparison, Chaucer's parody is extremely effectual in inviting readers to formulate conclusions about the marked distance between the ideal and the actual, the ideal being represented, in this particular case, by the courtly romance, and the actual, by the fabliau. The poet targets courtly and scriptural symbols for his parody; he describes the actual in terms of its imperfections and limitations, but his description calls upon the ideal, drawing upon the religious and/or courtly symbols the audience/reader is supposed to acknowledge.

Even though Linda Hutcheon stresses that her theory of parody applies only to twentiethcentury literature (ibid: 10), Chaucer's use of parody as a means of inviting comparison and judgment on the part of the reader (Reiss, 1973: 27) has tempted scholars to apply this theory to the Tales. Chaucer's parody is a multi-layered construction in that it intersperses the symbols of the ideal world (mostly religious), derived from the doctrinal authority of the church, with their crude misrepresentations by several pilgrims (the Miller being our case in point), whose behavioural and narrative transgression(s) become potential sources of character assessment. With its paradoxically ambivalent nature as "both authority and its transgression" (Hutcheon, 1985: 106), parody enables Chaucer to pinpoint his pilgrims on a characterological map: they can be respected, enhanced, berated, demoted, or simply made fun of.

The churlish Miller, however, is to play an important part in Chaucer's interplay of the ideal and the actual, that of challenging the fundamental values employed by the ruling classes (the aristocracy and the clergy) in the preservation of social order. The poet takes precautions in entreating that "eek men shal nat make ernest of game" (MP: 78), and makes sure that the Miller is laughable enough as not to attract too much attention, let alone condemnation, to his impiety. However, his drunken insurgency would not have gone unnoticed in Chaucer's day: fed up with the chivalric conventionalism of Athenian princes and nobles, and mindful that the Host, full of class-conscious zeal, might throw him at the back of the story-telling roster, Robin the Miller voices his frustration and takes control of the narrative flow, moving beyond the comic convention of the lower classes' symbolic revolt against authority, materialized in several medieval holidays, such as the Holy Innocents Day, when choir boys masqueraded as bishops and cardinals singing the Deposuit psalm (Owen, 1977: 105).

A deliberate butt of ridicule, drunken and grotesque in terms of physical appearance, the Miller hijacks the order of the story-telling contest because his intempestive intervention serves his creator's purpose of questioning the validity of the courtly love concept through a parody of courtly romance. Indeed, although it professes to be about love, the Knight's Tale is almost completely devoid of sex, whereas the Miller's Tale is the first of the Canterbury Tales that tackles obliquely the subject of human sexuality. Churlish, irreverent, jovial and rebellious, Robin the Miller overturns the expectations of the medieval social hierarchy, as his symbolic positioning against the Knight subverts the latter's aristocratic narrative of love by proposing a hypothetical alternative to the normative take on human 
sexuality. What if, the Miller's tale of peasant "harlotrye" dare ask, love is something more than the conventional courtship ritual? What if love-making, that is sex for pleasure, is something healthy and natural, and not something dirty, repulsive and sinful, as the church authorities still taught the people in the fourteenth century? The Miller's description of the sexually natural (in his portrayal of Alison of Oxford) amounts to an attitude towards sexuality that can be deemed "the religion of love" (David, 1976: 95-6), a worship of life that rejects the mortification of the flesh and creates its own rationale and moral justification in celebrating the joy of life (ibid.).

On the face of it, the Miller's bold assertion is simply heretical from the standpoint of the theoretical teachings of the Church fathers. The Christian doctrine fashioned, as it were, after the writings of St Augustine of Hippo established a consistent set of rules to define acceptable sexual behaviour. Out of the three admissible forms of sexual existence - virginity, widowhood and marriage - marriage was regarded as the least perfect, and the only one that still allowed for sexual activity. Doctrinally and ideally speaking, a virgin (male or female) and a widow(er) were creatures consecrated to God and not to worldly pursuits. As for married Christians, although guilty of the sin of concupiscence, they were allowed to enjoy the single morally condonable type of sexual activity - sex within wedlock, but with a series of restrictions as to the designated times and reasons to engage in sexual intercourse. The pain caused by the sin of concupiscence, Augustine theorizes in The Excellence of Marriage, is assuaged by the three goods of marriage, which stand for those particular circumstances when sex is permitted: the conception of children, the faithfulness of spouses, and the sacramental nature of marriage. However, while deriving scriptural legitimacy for these three goods, the church father is still exhorting against all sexual activity:

These things, namely, offspring, fidelity and the sacrament, are all good, and because of them marriage is good. In this age, however, it is certainly better and holier not to set out to have children physically, and so to keep oneself free from any activity of that kind, and to be subject spiritually to only one man, Christ. (1999, 57, italics mine)

Chaucer's contemporaries were well aware that except for marital intercourse, whose standard of moral judgment was debatable, other forms of sexual activity outside marriage, such as adultery and fornication, violated the doctrinal guidelines and were mortally sinful. The intended audience of The Canterbury Tales supposedly possessed an applied knowledge of doctrine and was competent enough to decode Chaucer's frequent use of biblical imagery and biblical allusions in line with the ideal championed by the church. This ideal of sexual behaviour is appropriated contextually by Chaucer's protagonists who enact actual scenarios in which marital sex or abstinence are depicted with a high degree of parodic intent. The doctrinal standard of the church frowned upon sex even when it was lawful, and it actively discouraged all representations of sexual activity that suggested joy of life, love and pleasure. The poet feels thus entitled to mediate the dispute between the ideal standard for sex and its actual enactment in the real world. He knows for a fact that Christian men and women can and do enjoy sexual activity, with its range of positive emotions that do not exclude joy of life, love and pleasure. This is why many of Chaucer's protagonists, married or not, try to circumvent the rigid doctrinal norm and accommodate their mundane understanding and performance of sex by occasionally appealing to the authority of the secular, human standard for sexual behaviour, the so-called code of courtly love.

In Chaucer's day, courtly love represented a formal code that regulated courtship, service and love-making, and derived its standards from highbrow literature. Although it is unclear whether the principles of courtly love were actually put into practice or not, the poet conjures its symbols and highlights its tenets as if the standards of courtly love possessed the same degree of validity as the standards of church doctrine. E. T. Donaldson argues that the idea of courtly love appeals to the basic human desire "to talk about love, especially a love that is suspected of being naughty, but whose naughtiness has attained archeological respectability" (1970: 155). The fact that courtly love alters the gender hierarchy established by church doctrine amounts to some respectability as well: whereas the medieval family is ruled, more or less oppressively, by the man, in courtly love the woman has the upper hand. Her symbolic dominance becomes immediately apparent in the complicated ritual of courtship, as the aspiring lover fears his lady's rejection but begs for her favour nonetheless. This favour is granted or refused as the lady pleases, and her attitude towards the lover, who threatens to die if he is 
rejected, is the cornerstone of the ritual, by the manipulation of which Chaucer plays upon courtly love as a source of parody. Particularly suitable to Chaucer's narratives of illicit love is the stipulation that courtly love can only exist between a man and a woman who are not each other's spouses (Capellanus, 106). As such, the fabliau, this coarse continental narrative of bawdy adventures, is the functional trope by which the poet succeeds in killing two birds with one stone: first, by sharing illicit love with courtly romances as its subject matter, the fabliau mocks the ritualistic pretence of courtship and calls into question the professedly sexless ideal of courtly love; and secondly, by superimposing the human standard (the performative dimension of sexual behaviour) over the ideal standard (the normative dimension of sexual behaviour), it parodies the doctrinal standards of the church as well.

Nowhere is Chaucer's parodic authorial design better exemplified than in the succession of the Miller's Tale immediately after the Knight's Tale, both being fashioned after the frame of a love triangle. While the Knight's aspiring lovers are both scrupulously idealistic, the Miller's mock-hero is a young lecherous student whose vulgar display of cunning wreaks havoc by comparison on the formalized ideals of courtly love, scoffs at religion and confounds the social hierarchy. Similarly, within the narrative framework of the Tales and outside its ideological bounds, the Miller wreaks havoc on all doctrinal pretences, bordering on blasphemy with his description of an adulterous act in terms of liturgical harmony, despite the fact that his story unfolds in the company of several notable members of the clergy (the Monk, the Prioress, and the Nun's Priest):

Withouten wordes mo, they goon to bedde

Theras the carpenter is wont to lye.

Ther was the revel and the melodye;

And thus lyth Alison and Nicholas,

In bissinesse of mirthe and of solas,

Til that the belle of Laudes gan to ringe,

And frères in the chauncel gonne singe. (MT: 542-548)

Chaucer has the Miller deliver the irreverent performance of his fabliau before an audience made up by an array of persons of different biases, whose strategies of interpretation and moral compass may at times come at odds with one another quite unpredictably, wherefore such an audience is designed to echo the views of a handful of stereotypical readers, whom the poet can control, instigate, assuage or dissuade. In the spirit of Chaucer's age and beyond it, the Miller's story of "harlotrye" appears to have been intended for the ears/eyes of a triad of such readers: the patristic, the literate and the mundane. These readerly categories may obviously overlap, but in general religious allusions invite a patristic reading that serves the purpose of reinstating the doctrinal order. For instance, the mentioning of the "belle of Laude" heard by the two carefree sinners also carries worldly implications, indicating the temporal expanse of their sexual trespassing, since any medieval Christian knew that the lauds, the first office of the day, were customarily sung between 3 and 4 a.m., before the break of day. Furthermore, the Miller's impious mention of "solas" associated with sexual activity rings a bell of discord with the well-read aristocrat, the Knight, whose moral tenets and fondness of romance tend to reject vulgar materiality and bespeak a metaphysical nostalgia that "mirrors a social and ethical nostalgia for a lost chivalric ideal which the Knight projects on to the tale's classical setting" (Miller, 2004: 82).

With the Miller's Tale, we can notice how audience/reader response, be it patristic, literate or mundane, helps to further the poet's parodic intent, while uncovering concentric layers of meaning that expose inherent tensions between religion and sex, desire and interdiction, language and thought, as well as other possible opposing terms stemmed from the dichotomy between the normative and the performative dimensions of western medieval sexuality. After all, the effects exacted by the normative grip of the church upon the sexually repressed western Middle Ages portrayed by Chaucer in his Tales, with their particularly subversive twist in the Miller's Tale, appear to indicate a "crisis of intelligibility in the emergent paradigm of western sexuality and romantic love" (ibid: 4), while Chaucer's morally ambiguous attitude towards the productions of his churlish narrators, the Miller in this case, his "sympathy and understanding in his presentation of the characters who tell fabliaux inevitably implies that the poet himself does not share their points of view but recognizes a standard from which their deviations may be viewed as comic" (Richardson, 1979: 102). Indeed, what Chaucer's tongue-in-cheek distancing from the heretical views upon human sexuality expressed by his Miller resembles the most 
is an unaided struggle to restore the balance of power between doctrinal inflexibility and humans' lifelong yearning for the natural.

Works Cited

Augustine, Saint, Bishop of Hippo. 1999. The Works of Saint Augustine, Marriage and Virginity, 1/9, Translation by Ray Kearney. Ed. John E. Rotelle. New City Press: Hyde Park, New York. Chaucer, G. 1973. "The Miller's Prologue and Tale", in The Oxford Anthology of English Literature, Vol. I, Frank Kermode \& John Hollander (eds.), Oxford University Press. 156-176. Herein referred to in quotations as $M P$ and $M T$.

David, A. 1976. The Strumpet Muse: Art and Morals in Chaucer's Poetry, Bloomington, IN: Indiana UP.

Donaldson, E. Talbot. 1970. Speaking of Chaucer, London: The Athlone Press.

Hutcheon, Linda. 1985. A Theory of Parody: The Teachings of Twentieth-Century Art Forms, New York: Methuen.

Miller, M. 2004. Philosophical Chaucer: Love, Sex, and Agency in the Canterbury Tales, Cambridge University Press.

Owen, C. A. Jr. 1977. Pilgrimage and Storytelling in the Canterbury Tales, Norman: University of Oklahoma Press.

Reiss, E. 1973. "Chaucer's Parodies of Love" Chaucer the Love Poet, Jerome Mitchell and William P. (ed). Athens: University of Georgia Press, 27-43.

Richardson, J. 1979. Blameth Nat Me: a Study of Imagery in Chaucer's Fabliaux, The Hague: Mouton De Gruyter. 